\title{
PENERAPAN PENDEKATAN BERMAIN \\ UNTUK MENINGKATKAN HASIL BELAJAR GERAK DASAR LARI
}

\author{
Risca Septiyani $^{(1)}$, Budhi Satyawan ${ }^{(2)}$ \\ ${ }^{(1)}$ Universitas Sebelas Maret Surakarta \\ ${ }^{(2)}$ Universitas Sebelas Maret Surakarta
}

\begin{abstract}
The purpose of this study is to improve the basic motion of runing on 6 grade students SD N Laweyan No.54 Surakarta academic year 2017/2018.

This research is classroom action research (CAR). This research was conducted in two cycle and every cycle consist of plan, implementation, observation and reflection. The subject of this research is student in grade 6 of SD $N$ Laweyan No.54 Surakarta that totaling 43 students, consist of 19 male students and 24 female students. Source of data derived from teachers, students and researcher. The validity of data use descriptive technique that based on qualitative analysis by percentage.

From the result of this research, the analysis obtained from initial condition of students who completed test only 18 students or $41,86 \%$ and not complete test is 25 students or $58,14 \%$, in the firt cycle students who completed to 32 students or $74,42 \%$ and not complete test is 11 students or $25,58 \%$, and in the second cycle students who completed to 36 students or $83,72 \%$ then 7 other students or 16,28\% have not completed with KKM is 75.

The conclution of this research is learning through play approach can improve learning result of basic motion run in 6 grade student of SD $N$ Laweyan No.54 Surakarta academic year 2017/2018.
\end{abstract}

Keywords : Learning outcome, Basic motion run, Playing approach. 


\section{PENDAHULUAN}

Atletik merupakan salah satu cabang olahraga dari Pendidikan Jasmani dan Kesehatan juga merupakan komponen-komponen pendidikan keseluruhan yang mengutamakan aktivitas jasmani serta pembinaan hidup sehat dan pengembangan jasmani, mental, sosial, dan emosional yang serasi, selaras, dan seimbang. Ketrampilan gerak dasar atletik sebaiknya mulai diajarkan kepada anak pada tahuntahun permulaan di Sekolah Dasar yaitu melalui berbagai bentuk gerakan berjalan, berlari, melompat dan melempar. Salah satu cabang olahraga atletik yang diajarkan di sekolah dasar adalah lari. Lari adalah gerakan melangkah dengan kecepatan tinggi, akan tetapi lari sangatlah berbeda dengan melangkah dikarenakan ketika kita melakukan lari kaki tidak bersamaan menyentuh tanah seperti kita berjalan. Usia anak didik yang masih muda dan perkembangan fisik yang belum mencapai tingkat kemampuan yang memadai maka pelajaran lari di tingkat Sekolah Dasar diberikan dalam bentuk permainan yang bersifat gembira dan menyenangkan.

Sesuai dengan karakteristik siswa sekolah dasar (SD) yang suka bermain, maka guru PJOK harus mampu mengembangkan pembelajaran yang efektif disamping harus mampu memahami dan memperhatikan karakteristik dan kebutuhan gerak peserta didik. Pembelajaran nomor lari dapat berhasil dengan baik, jika unsurunsur bermain diterapkan didalamnya serta dapat dijadikan pokok pertimbangan dalam penyelenggaraan. Lari merupakan cabang olahraga atletik yang paling dasar dari cabang-cabang olahraga yang ada dalam atletik. Kesulitan dalam melaksanakan gerak dasar lari itu sendiri menjadi salah satu permasalahan yang sering dihadapi oleh guru maupun peserta didik di dalam pembelajaran. Gerak dominan yang utama dari gerak dasar lari adalah gerakan langkah kaki dan ayunan lengan.

Permasalahan dalam pembelajaran gerak dasar lari juga ditemukan di SD Negeri Laweyan 
No.54 Surakarta, hal ini diketahui dari hasil observasi selama melaksanakan kegiatan Program Pengalaman Lapangan yang telah dilaksanakan di sekolah tersebut diatas. Hasil observasi menunjukkan bahwa guru penjasorkes di sekolah tersebut belum pernah membelajarkan gerak dasar lari dengan pendekatan bermain, padahal disini untuk anak-anak Sekolah Dasar gemar bermain. Pembelajaran atletik gerak dasar lari yang dilakukan oleh siswa masih banyak mengalami kesalahan. Kesalahan tersebut diantaranya adalah, panjang langkah kaki yang terlalu sempit, ayunan lengan yang tidak seimbang dengan langkah kaki, badan yang tidak condong ke depan, dan napas yang tidak teratur sehingga menyebabkan hasil belajar yang diperoleh kurang optimal.

Hal ini disebabkan oleh pendekatan pembelajaran yang diterapkan oleh guru masih menekankan sistem latihan yang berulang-ulang sehingga menjadikan proses pembelajaran menjadi monoton dan tidak menarik. Dalam memberikan materi guru hanya menjelaskan teknik berlari saja tanpa dikemas dalam bentuk permainan. Ketika pembelajaran sedang berlangsung siswa hanya melakukan teknik berlari secara berulang-ulang dengan media pembelajaran ban bekas yang disusun membentuk zigzag dan alat bantu sejenis poa saja.

Banyak siswa yang malas dan kurang berminat dalam melaksanakan kegiatan yang diberikan oleh guru karena dipandang bahwa lari adalah kegiatan yang melelahkan bagi anak. Berdasarkan observasi yang telah dilaksanakan bahwa faktor utama yang menyebabkan kurang optimalnya keberhasilan pembelajaran dalam gerak dasar lari adalah bahwa guru kurang variasi dalam mengemas proses pembelajarannya sehingga siswa merasa jenuh dan kurang berkonsentrasi ketika pembelajaran lari sedang berlangsung. Pendekatan pembelajaran yang dilakukan guru seperti diatas banyak mengalami kendala yang mengakibatkan rendahnya hasil belajar gerak dasar lari pada siswa kelas VI SD Negeri Laweyan No.54 Surakarta. Berikut 
ini hasil belajar gerak dasar lari pada siswa kelas VI di sekolah tersebut diatas pada tahun pelajaran 2016/2017. Hasil pembelajaran pada kondisi awal yang diperoleh dari jumlah siswa 43 hanya $41,86 \%$ atau 18 siswa yang dinyatakan tuntas, sedangkan 58,14\% atau 25 siswa dinyatakan belum tuntas. Dengan standar kriteria ketuntasan minimal (KKM) yang ditetapkan adalah 75 . (Sumber : Data Sekolah)

Salah satu pendekatan pembelajaran yang akan diterapkan dalam mengatasi permasalahan rendahnya hasil belajar gerak dasar lari pada siswa kelas VI SD Negeri Laweyan No.54 Surakarta adalah pendekatan pembelajaran dengan bermain. Pendekatan bermain merupakan bentuk pembelajaran yang mengaplikasikan gerak dasar ke dalam suatu permainan atau belajar teknik dasar suatu cabang olahraga yang disusun dalam bentuk permainan. Dengan bermain siswa dapat mengembangkan fisik, mental, emosional, intelektual, dan sosial anak seusia mereka. Melalui pendekatan bermain, diharapkan pembelajaran gerak dasar lari akan memperoleh hasil belajar yang optimal. Jadi dengan pendekatan bermain siswa akan lebih senang, aktif dan bersemangat lagi dalam mengikuti pembelajaran gerak dasar lari yang diberikan oleh guru. Karena di dalam pendekatan bermain banyak mengandung unsur-unsur permainan yang telah dikemas dengan baik untuk diterapkan di dalam proses pembelajaran penjasorkes di sekolah dasar.

\section{METODE}

Metode penelitian yang digunakan adalah Penelitian Tindakan Kelas. Subjek yang diteliti dalam Penelitian Tindakan Kelas ini adalah semua siswa kelas VI SD N Laweyan No.54 Surakarta tahun ajaran 2017 / 2018, semester I. Jumlah siswa kelas VI yaitu sejumlah 43 siswa dengan jumlah siswa perempuan sebanyak 24 siswa dan siswa laki-lakinya sebanyak 19 siswa.

Teknik pengumpulan data dalam Penelitian Tindakan Kelas ini terdiri atas: tes dan observasi. Tes digunakan untuk mendapatkan data tentang hasil belajar gerak dasar lari 
pada siswa serta hasil tes tulis yang diberikan oleh guru.

Observasi, digunakan sebagai teknik untuk mengumpulkan data tentang aktivitas siswa dalam mengikuti proses belajar mengajar tentang gerak dasar lari pada siswa dengan menggunakan pendekatan bermain.

\section{HASIL DAN PEMBAHASAN}

\section{Hasil}

Hasil pengamatan pada data awal, siklus 1, dan siklus 2 terdapat peningkatan gerak dasar lari melalui pendekatan bermain pada siswa kelas VI SD N Laweyan No.54 Surakarta pada data awal yang lulus hanya 18 siswa atau $41.86 \%$ sedangkan pada siklus 1 meningkat menjadi 32 atau $74,42 \%$ ini juga merupakan capaian pada siklus 1 sehingga siswa yang tuntas masih jauh dari target $80 \%$. Sehingga perlu dilakukan siklus 2, dalam siklus 2 terjadi peningkatan yang melebihi target capaian yaitu 36 siswa yang tuntas atau $83,72 \%$ sehingga penelitian ini berhenti pada siklus ke 2. Peningkatan ini hasil rekapan nilai dari 3 ranah yaitu ranah kognitif, afektif dan psikomotor.

\section{Pembahasan}

Berdasarkan hasil pelaksanaan pada data awal, siklus 1 , dan siklus 2 dapat ditarik kesimpulan bahwa terjadi peningkatan hasil belajar Gerak Dasar Lari Melalui Pendekatan Bermain Pada Siswa Kelas VI SD N Laweyan No.54 Surakarta Tahun Ajaran 2017/2018.

Dalam proses pembelajaran gerak dasar lari berjalan baik dan menyenangkan serta siswa tidak takut lagi kakinya sakit, tidak lagi meminta permainan sepak bola/kasti dan tidak lagi mengeluh bosan sehingga pembelajaran berjalan efektif dan efisien siswa antusias dalam pembelajaran gerak dasar lari sehingga meningkatkan hasil pembelajaran gerak dasar lari. Berikut ini masing-masing data jumlah siswa yang tuntas dan persentase dari setiap penelitian ini.

$$
\text { Pada kondisi awal siswa }
$$
masih belum memperoleh hasil yang maksimal banyak siswa yang belum sesuai dengan yang diharapkan. Pada pembelajaran siklus 1 terjadi peningkatan dari yang kondisi awal 18 siswa atau $41,86 \%$ menjadi 32 
siswa atau 74,42\%. Pada siklus 1 hasil belajar siswa belum mencapai target yang ditentukan yaitu $80 \%$ dikarenakan beberapa siswa ada yang kurang semangat dalam mengikuti pembelajaran,tidak mau pindah ke pos berikutnya dan ramai sendiri serta mengobrol dengan temannya. Perbaikan dari siklus 1 dengan menambah alat pembelajaran yaitu kardus pada permainan berlomba mengibarkan bendera dan tong sampah pada permainan berebut harta karun, serta menambah waktu percobaan dari 3 menit menjadi 5 menit disetiap posnya. Sedangkan pada siklus 2 terjadi peningkatan yang sudah melebihi target capaian yaitu 36 siswa atau $83,72 \%$.

Pada siklus 2 sebagian besar siswa mampu melakukan gerak dasar lari dengan baik dan benar cuma sedikit siswa yang belum menguasai atau belum melakukan gerak dasar lari dengan benar malah ada siswa yang melakukan gerak dasar lari dengan baik karenan selain disekolah dirumah anak itu juga melakukan gerakan dasar lari hanya beberapa siswa yang belum menguasai gerak dasar lari dengan baik dan benar PHEDHERAL VOL. 15 No. 1, Mei 2018 sehingga belum bisa melewati KKM. Siswa juga sangat antusias dan aktif dalam melakukan gerakan-gerakan gerak dasar lari karena siswa merasa senang dengan permainan-permainan yang dilakukan dan sudah tidak merasa kakinya sakit, capek dan mengeluh bosan pada saat pembelajaran. Untuk memperjelas perkembangan ketuntasan hasil belajar siswa dari kondisi awal,siklus1 dan siklus 2 disajikan dalam tabel sebagai berikut:

Dalam kondisi awal
ketuntasan hasil belajar sangat
kurang hanya 18 siswa yang tuntas
25 siswa lainnya belum, setelah tindakan siklus 1 terjadi peningkatan hasil belajarnya menjadi 32 siswa yang tuntas dan hanya 11 siswa yang belum tuntas. Dan pada siklus ke 2 kembali terdapat peningkatan menjadi 36 siswa yang tuntas dan 7 yang belum tuntas.

Melalui peningkatan yang terjadi sejak kondisi awal hingga diberikan tindakan siklus 1 dan siklus 2 dapat disimpulkan bahwa melalui pendekatan bermain pada siswa kelas VI SD N Laweyan No.54 Surakarta Tahun Ajaran 2017/2018 
hasil belajar gerak dasar lari siswa dapat meningkat.

\section{SIMPULAN DAN SARAN}

\section{Simpulan}

Penelitian Tindakan kelas pada siswa kelas VI SD N Laweyan No.54 Surakarta Tahun Ajaran 2017/2018 dilaksanakan pada dua siklus 1 dan siklus 2. Setiap siklus terdiri dari empat tahapan, yaitu (1) perencanaan: (2) pelaksanaan, (3) observasi, (4) refleksi.

Dari hasil analisis diperoleh peningkatan dari siklus I dan siklus II, pada siklus I untuk materi gerak dasar lari sebanyak (74,42\%) 32 siswa tuntas dan $(25,58 \%) 11$ siswa belum tuntas dari jumlah 43 siswa. Pada siklus II pembelajaran gerak dasar lari melalui pendekatan bermain telah mencapai target capaian yang sudah ditetapkan yaitu 36 siswa tuntas $(83,72 \%)$ dan 7 siswa belum tuntas $(16,28 \%)$ dari jumlah 43 siswa.

Dari analisis data yang dikemukakan di atas dapat ditarik kesimpulan bahwa penerapan pendekatan bermain dapat meningkatkan hasil belajar gerak dasar lari pada peserta didik kelas VI SD N Laweyan No.54 Surakarta Tahun Ajaran 2017/2018.

\section{Saran}

Sehubungan dengan simpulan yang telah diambil, disarankan halhal sebagai berikut:

1. Guru penjasorkes jika memberikan materi gerak dasar lari pada siswa nya sebaiknya menggunakan pendekatan bermain, agar hasil belajar siswa SD $\mathrm{N}$ Laweyan No.54 Surakarta dapat meningkat menjadi lebih baik, maksimal dan memuaskan.

2. Guru yang menggunakan permainan itu-itu saja atau permainan yang monoton hendaknya guru mencoba mengembangkan permainan-permainan yang digunakan dan harus mampu membuat atau menciptakan permainan yang tepat bahkan permainan baru yang belum pernah ada sebelumnya agar dapat bermanfaat untuk meningkatkan hasil belajar siswanya.

3. Bagi sekolah, semoga penelitian ini bermanfaat dan 
diterapkan pada saat pembelajaran solusi dalam pembelajaran gerak gerak dasar lari dan bisa menjadi dasar lari.

\section{DAFTAR PUSTAKA}

Ade Mardiana.(2014). Pendidikan Jasmani dan Olahraga. Tangerang Selatan: Universitas Terbuka.

Agus Kristiyanto. (2010). Penelitian Tindakan Kelas (PTK) dalam Pendidikan Jasmani \& Kepelatihan Olahraga. Surakarta: UNS Press.

Agus Taufiq. (2015). Pendidikan Anak di SD. Tangerang Selatan: Universitas Terbuka.

Amung Ma'mun \& Yudha M.Saputra,. (2000).Perkembangan Gerak dan Belajar Gerak. Jakarta: Departemen Pendidikan dan Kebudayaan.

Dikdik Zafar Sidik. (2010). Mengajar dan Melatih Atletik.Bandung : PT Remaja Rosdakarya.

Giri Wiarto. (2013). Atletik. Yogyakarta : Graha Ilmu.

H.JS.Husdarta \& Yudha M.Saputra. (2013).Belajar dan Pembelajaran Pendidikan Jasmani dan Kesehatan.Bandung : Alfabeta.

Ikee Proklamasi A.(2016). Gerak Dasar. Bandung : Alfabeta.

Jamal Ma’mur Asmani.(2011a). Penelitian Tindakan Kelas . Jogjakarta: Laksana.

Jamal Ma'mur Asmani. (2011b). 7 Tips Aplikasi PAIKEM . Jogjakarta: DIVA Press.

Oemar Hamalik. (2014). Kurikulum dan Pembelajaran. Jakarta: PT Bumi Aksara.

Rosdiani, D. (2013a).Model Pembelajaran Langsung dalam Pendidikan Jasmani dan Kesehatan.Bandung: Alfabeta.

Rosdiani, D. (2013b).Perencanaan Pembelajaran dalam Pendidikan Jasmani dan Kesehatan.Bandung : Alfabeta.

Samsudin. (2010). Pembelajaran Pendidikan Jasmani Olahraga dan Kesehatan SD/MI. Jakarta: Prenada Media Group.

Saur M. Tampubolon. (2014). Penelitian Tindakan Kelas. Jakarta: Erlangga.

Slameto. (2010). Belajar dan Faktor-Faktor Yang Mempengaruhinya. Jakarta: PT Asdi Mahasatya. 